BLOOD GROUPS, HAEMOGLOBINS, AND TIIALASSAEMIA IN TURKS IN SOUTHERN TURKEY AND ETI-TURKS

BY

M. AKSOY, M.D.

Beyoglu Ilk Yardim Hastanesi, Beyoglu, Istanbul

AND

ELIZABETH W. IKIN, B.Sc.

A. E. MOURANT, D.Phil., D.M., M.R.C.P. Blood Group Reference Laboratory (M.R.C.), Lister Institute, London

AND

H. LEHMANN, M.D., Sc.D., M.R.C.P., F.R.I.C. Department of Pathology, St. Bartholomew's Hospital, London

The results of a number of surveys of the ABO blood groups of the Turkish population have been published. We do not, however, know of any observations hitherto published on the other blood-group systems. There have been numerous previous publications on thalassaemia in the Turkish population, but the only published work on haemoglobins (apart from isolated cases of sickling) has been that carried out by two of the present authors and their collaborators.

The present survey arose out of the discovery by one of us (Aksoy, 1955) of a focus of sickling among the Eti-Turks, a small Arabic-speaking population living near Mersin, in southern Turkey. The occurrence of thalassaemia and of sickle-cell thalassaemia (Crowiey et al., 1957 ; Aksoy and Lehmann, 1957a ; Aksoy. 1958) has subsequently been described in this population. When further investigations were organized the opportunity was taken of carrying out blood-grouping tests on EtiTurks and of examining a control sample of Turks from the same region. From the Eti-Turks 138 specimens were obtained, of which 108 were examined for blood groups. The specimens were taken from persons attending a hospital out-patient department, and are known to have included an excessive number suffering from haemoglobinopathies. This is unlikely to have affected the blood-group frequencies appreciably, but the inclusion of a number of relatives of patients may have had some slight effect, by exaggerating the frequencies of those genes that happened to be present in these families. Specimens were obtained also from 240 unselected and unrelated Turks, and 108 of these were examined for blood groups.

\section{Blood Groups}

Most or all of the specimens were tested for the antigens $A_{1}, A_{2}, B, M, N, S, C, C^{w}, c, D, D u, E, e, L u^{a}, K$. and Fya The results of our tests and of gene-frequency calculations are given in Tables $1-V I I I$.

TABLE I.-The $A_{1} A_{2} B O$ Blood Groups of the Turks of Mersin

\begin{tabular}{|c|c|c|c|c|c|c|}
\hline $\begin{array}{l}\text { Blood } \\
\text { Group }\end{array}$ & $\begin{array}{c}\text { No. } \\
\text { Observed }\end{array}$ & $\begin{array}{l}\text { Frequency } \\
\text { Observed }\end{array}$ & $\begin{array}{l}\text { Frequency } \\
\text { Expected }\end{array}$ & $\begin{array}{c}\text { No. } \\
\text { Expected }\end{array}$ & \multicolumn{2}{|c|}{$\begin{array}{c}\text { Gene } \\
\text { Frequencies }\end{array}$} \\
\hline $\begin{array}{l}O \\
\mathbf{A}_{1} \\
\mathbf{A}_{2} \\
\mathbf{B} \\
\mathbf{A}_{1} \mathbf{B} \\
\mathbf{A}_{2} \mathbf{B}\end{array}$ & $\begin{array}{r}35 \\
34 \\
9 \\
20 \\
8 \\
2\end{array}$ & $\begin{array}{l}0.3241 \\
0.3148 \\
0.0833 \\
0.1852 \\
0.0741 \\
0.0185\end{array}$ & $\begin{array}{l}0.3189 \\
0.3227 \\
0.0813 \\
0.1915 \\
0.0652 \\
0.0203\end{array}$ & $\begin{array}{r}34.44 \\
34.85 \\
8.78 \\
20.69 \\
7.04 \\
2.20\end{array}$ & $\begin{array}{lll}p_{1} & \ldots\left(A_{1}\right) \\
p_{2} & \ldots & \left(A_{2}\right) \\
q & \ldots & (B) \\
r & \ldots & (O)\end{array}$ & $\begin{array}{lll}\ldots & 0 & 2176 \\
\ldots & 0.0679 \\
\ldots & 0.1497 \\
\ldots & 0.5647\end{array}$ \\
\hline & 108 & 1.0000 & 0.9999 & $108 \cdot 00$ & Total & .. 0.9999 \\
\hline
\end{tabular}

TABLE II.-The MNS Blood Groups of the Turks of Mersin

\begin{tabular}{|c|c|c|c|c|c|c|c|}
\hline $\begin{array}{c}\text { Pheno- } \\
\text { type }\end{array}$ & $\begin{array}{c}\text { No. } \\
\text { Observed }\end{array}$ & $\begin{array}{l}\text { Frequency } \\
\text { Observed }\end{array}$ & $\begin{array}{c}\text { Frequency } \\
\text { Expected }\end{array}$ & $\begin{array}{c}\text { No. } \\
\text { Expected }\end{array}$ & \multicolumn{3}{|c|}{$\begin{array}{l}\text { Chromosome } \\
\text { Frequencies }\end{array}$} \\
\hline $\begin{array}{l}\text { MMS } \\
\text { MsMs } \\
\text { MNS } \\
\text { MsNs } \\
\text { NNS } \\
\text { NsNs }\end{array}$ & $\begin{array}{r}18 \\
9 \\
24 \\
28 \\
10 \\
19\end{array}$ & $\begin{array}{l}0.1667 \\
0.0833 \\
0.2222 \\
0.2593 \\
0.0926 \\
0.1759\end{array}$ & $\begin{array}{l}0.1508 \\
0.0900 \\
0.2478 \\
0.2521 \\
0.0829 \\
0.1764\end{array}$ & $\begin{array}{c}16 \cdot 29 \\
9.72 \\
26 \cdot 76 \\
27.22 \\
8.96 \\
19.05\end{array}$ & $\begin{array}{l}\text { MS } \\
\text { Ms } \\
\text { NS } \\
\text { Ns }\end{array}$ & $\begin{array}{l}. \\
\because \\
.\end{array}$ & $\begin{array}{l}0.1907 \\
0.3001 \\
0.0892 \\
0.4200\end{array}$ \\
\hline Total & 108 & 1.0000 & 1.0000 & 108.00 & Total & . & 1.0000 \\
\hline
\end{tabular}

TABLE III.-The Rh Blood Groups of the Turks of Mersin

\begin{tabular}{|c|c|c|c|c|c|c|}
\hline $\begin{array}{c}\text { Pheno- } \\
\text { type }\end{array}$ & $\begin{array}{l}\text { No. } \\
\text { Observed }\end{array}$ & $\begin{array}{l}\begin{array}{l}\text { Frequency } \\
\text { Observed }\end{array}\end{array}$ & $\begin{array}{c}\text { Frequency } \\
\text { Expected }\end{array}$ & $\begin{array}{c}\text { No. } \\
\text { Expected }\end{array}$ & \multicolumn{2}{|c|}{$\begin{array}{l}\text { Chromosome } \\
\text { Frequencies }\end{array}$} \\
\hline $\begin{array}{l}\text { CCDee } \\
\text { CcDee } \\
\text { CcDEe } \\
\text { ccDEe } \\
\text { ccDEE } \\
\text { ccDee } \\
\text { Ccddee } \\
\text { CCddee } \\
\text { ccddee }\end{array}$ & $\begin{array}{r}25 \\
35 \\
21 \\
10 \\
3 \\
1 \\
1 \\
0 \\
12\end{array}$ & $\begin{array}{l}0.2315 \\
0.3241 \\
0.1944 \\
0.0926 \\
0.0278 \\
0.0093 \\
0.0093 \\
0.1111\end{array}$ & $\begin{array}{l}0.2452 \\
0.3210 \\
0.1697 \\
0.1142 \\
0.0293 \\
0.0085 \\
0.0093 \\
0.0002 \\
0.1026\end{array}$ & $\begin{array}{r}26.48 \\
34.67 \\
18.33 \\
12.33 \\
3.17 \\
0.92 \\
1.00 \\
0.02 \\
11.08\end{array}$ & $\begin{array}{l}\text { CDe } \\
\text { cDE } \\
\text { cDe } \\
\text { Cde } \\
\text { cde }\end{array}$ & $\begin{array}{ll}\ldots & 0.4809 \\
\ldots & 0.1713 \\
\ldots & 0.0131 \\
. . & 0.0145 \\
\ldots & 0.3203\end{array}$ \\
\hline Total & 108 & 1.0001 & 1.0000 & 108.00 & Tota & 1.0001 \\
\hline
\end{tabular}

TABLE IV.-The Lutheran, Kell, and Duffy Blood Groups of the Turks of Mersin

\begin{tabular}{|c|c|c|c|c|}
\hline Phenotype & $\begin{array}{c}\text { No. } \\
\text { Observed }\end{array}$ & $\begin{array}{l}\text { Frequency } \\
\text { Observed }\end{array}$ & Gene & Frequency \\
\hline $\begin{array}{l}\operatorname{Lu}(\mathbf{a}+) \\
\mathbf{L u}(\mathbf{a}-)\end{array}$ & $\begin{array}{r}3 \\
105\end{array}$ & $\begin{array}{l}0.0278 \\
09722\end{array}$ & $\begin{array}{l}\text { Lus } \\
\text { Lub }\end{array}$ & $\begin{array}{ll}\ldots & 000140 \\
. & 0.9860\end{array}$ \\
\hline $\begin{array}{l}\mathbf{K}+ \\
\mathbf{K}-\end{array}$ & $\begin{array}{r}4 \\
103\end{array}$ & $\begin{array}{l}0.0374 \\
0.9626\end{array}$ & $\underset{\mathbf{k}}{\mathbf{K}}$ & $\begin{array}{ll}\therefore & 0.0189 \\
\therefore & 0.9811\end{array}$ \\
\hline $\begin{array}{l}\text { Fy(a+) } \\
\text { Fy(a-) }\end{array}$ & $\begin{array}{l}79 \\
28\end{array}$ & $\begin{array}{l}0.7383 \\
0.2617\end{array}$ & $\begin{array}{l}\text { Fy" } \\
\text { Fyb }\end{array}$ & $\begin{array}{ll}\ldots & 0.4885 \\
\ldots & 0.5115\end{array}$ \\
\hline
\end{tabular}

TABLE V.-The $A_{1} A_{2} B O$ Blood Groups of the Eti-Turks

\begin{tabular}{|c|c|c|c|c|c|}
\hline $\begin{array}{l}\text { Blood } \\
\text { Group }\end{array}$ & $\begin{array}{c}\text { No. } \\
\text { Observed }\end{array}$ & $\begin{array}{l}\text { Frequency } \\
\text { Observed }\end{array}$ & $\begin{array}{c}\text { Frequency } \\
\text { Expected }\end{array}$ & $\begin{array}{c}\text { No. } \\
\text { Expected }\end{array}$ & $\begin{array}{c}\text { Gene } \\
\text { Frequencies }\end{array}$ \\
\hline $\begin{array}{l} \\
\mathbf{A}_{1} \\
\mathbf{A}_{2} \\
\mathbf{B}^{2} \\
\mathbf{A}_{1} \mathbf{B} \\
\mathbf{A}_{2} \mathbf{B}\end{array}$ & $\begin{array}{r}43 \\
43 \\
12 \\
14 \\
4 \\
2\end{array}$ & $\begin{array}{l}0.3644 \\
0.3644 \\
0.1017 \\
0.1186 \\
0.0339 \\
0.0169\end{array}$ & $\begin{array}{l}0.3670 \\
0.3589 \\
0.1044 \\
0.1155 \\
0.0399 \\
0.0143\end{array}$ & $\begin{array}{r}43.31 \\
42.35 \\
12.32 \\
13.63 \\
4.71 \\
1.69\end{array}$ & $\begin{array}{lllll}\mathrm{p}_{1} & \ldots & \left(\mathrm{A}_{1}\right) & \ldots & 0.2246 \\
\mathrm{p}_{2} & \ldots & \left(\mathrm{A}_{2}\right) & \ldots & 0.0808 \\
\mathrm{q}_{2} & \ldots & (\mathrm{B}) & \ldots & 0.0888 \\
\mathrm{r} & \ldots & (\mathrm{O}) & \ldots & 0.6058\end{array}$ \\
\hline Total & 118 & 0.9999 & 1.0000 & 118.01 & $\ldots 1.0000$ \\
\hline
\end{tabular}

TABLE VI.-The MNS Blood Groups of the Eti-Turks

\begin{tabular}{|c|c|c|c|c|c|c|}
\hline $\begin{array}{c}\text { Pheno- } \\
\text { type }\end{array}$ & $\begin{array}{c}\text { No. } \\
\text { Observed }\end{array}$ & $\begin{array}{c}\text { Frequency } \\
\text { Onserved }\end{array}$ & $\begin{array}{c}\text { Frequency } \\
\text { Expected }\end{array}$ & $\begin{array}{c}\text { No. } \\
\text { Expected }\end{array}$ & \multicolumn{2}{|c|}{$\begin{array}{l}\text { Chromosome } \\
\text { Frequencies }\end{array}$} \\
\hline $\begin{array}{l}\text { MMS } \\
\text { MsMs } \\
\text { MNS } \\
\text { MsNs } \\
\text { NNS } \\
\text { NsNs }\end{array}$ & $\begin{array}{l}36 \\
7 \\
28 \\
19 \\
10 \\
16\end{array}$ & $\begin{array}{l}0.3103 \\
0.0603 \\
0.2414 \\
0.1638 \\
0.0862 \\
0.1379\end{array}$ & $\begin{array}{l}02614 \\
0.0673 \\
0.3117 \\
0.1776 \\
0.0649 \\
0.1172\end{array}$ & $\begin{array}{r}30.32 \\
7.81 \\
3615 \\
2060 \\
7.53 \\
13.59\end{array}$ & $\begin{array}{l}\text { MS } \\
\text { Ms } \\
\text { NS } \\
\text { Ns }\end{array}$ & $\begin{array}{ll}. & 0.3139 \\
\ldots & 0.2594 \\
\ldots & 0.0844 \\
. & 0.3423\end{array}$ \\
\hline Total & 116 & 0.9999 & 1.0001 & 116.00 & Tota & 1.0000 \\
\hline
\end{tabular}

TABLE VII.-The Rh Blood Groups of the Eti-Turks

\begin{tabular}{|c|c|c|c|c|c|c|}
\hline $\begin{array}{c}\text { Pheno- } \\
\text { type }\end{array}$ & $\begin{array}{c}\text { No. } \\
\text { Observed }\end{array}$ & $\begin{array}{l}\text { Froquency } \\
\text { Observed }\end{array}$ & $\begin{array}{c}\text { Frequency } \\
\text { Expected }\end{array}$ & $\begin{array}{c}\text { No. } \\
\text { Expocted }\end{array}$ & \multicolumn{2}{|c|}{$\begin{array}{l}\text { Chromosome } \\
\text { Frequencies }\end{array}$} \\
\hline $\begin{array}{l}\text { CCDee } \\
\text { CCD"ee } \\
\text { CcDee } \\
\text { CcDuee } \\
\text { CcDEe } \\
\text { ccDEe } \\
\text { ccDEE } \\
\text { ccDee } \\
\text { ccddee }\end{array}$ & $\begin{array}{r}33 \\
0 \\
42 \\
4 \\
17 \\
6 \\
4 \\
1 \\
11\end{array}$ & $\begin{array}{l}0.2797 \\
0.3559 \\
0.0339 \\
0.1441 \\
0.0508 \\
0.0339 \\
0.0085 \\
0.0932\end{array}$ & & $\begin{array}{r}34.90 \\
0.36 \\
37.54 \\
4.00 \\
16.94 \\
9.94 \\
2.04 \\
1.02 \\
11.22\end{array}$ & $\begin{array}{l}C D e \\
C D{ }^{\circ} \\
\text { cDE } \\
\text { cDe } \\
\text { cde }\end{array}$ & 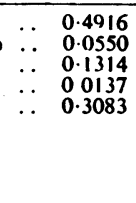 \\
\hline Total & 118 & & 1.0001 & 118.00 & Total & 1.0000 \\
\hline
\end{tabular}


TABLE VIII.-The Lutheran, Kell, and Duffy Blood Groups of the Eti-Turks

\begin{tabular}{|c|c|c|c|c|}
\hline Phenotype & $\begin{array}{c}\text { No. } \\
\text { Observed }\end{array}$ & $\begin{array}{l}\text { Froquency } \\
\text { Observed }\end{array}$ & Gene & Frequency \\
\hline $\begin{array}{l}\operatorname{Lu}(\mathbf{a}+) \\
\mathbf{L u}(\mathbf{a}-)\end{array}$ & 115 & $\begin{array}{l}0.0086 \\
0.9914\end{array}$ & $\begin{array}{l}\mathbf{L u}^{*} \\
\text { Lu }^{\mathbf{b}}\end{array}$ & $\begin{array}{ll}\ldots & 0.0043 \\
\ldots & 0.9957\end{array}$ \\
\hline$\underset{\mathbf{K}}{\mathbf{K} \pm}$ & $\begin{array}{r}12 \\
104\end{array}$ & $\begin{array}{l}0.1034 \\
0.8966\end{array}$ & $\underset{\mathbf{k}}{\mathbf{K}}$ & 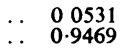 \\
\hline $\begin{array}{l}\text { Fy }(a+) \\
\text { Fy(a-) }\end{array}$ & $\begin{array}{l}78 \\
38\end{array}$ & $\begin{array}{l}0.6724 \\
0.3276\end{array}$ & $\begin{array}{l}\text { Fy } \\
\text { Fyb }\end{array}$ & $\begin{array}{ll}\ldots & 0.4276 \\
\ldots & 0.5724\end{array}$ \\
\hline
\end{tabular}

Observations on the distribution of the ABO blood groups in Turkey by Aygen (1946), Babacan (1937), Irmak (1938), and Onur $(1937,1957)$ (brought together and tabulated by Mourant et al., 1958) show that nearly all Turkish populations have A-gene frequencies between 24 and $33 \%$, these being on the whole higher than in Eastern Europe apart from Bulgaria and parts of Rumania and Hungary, but also higher than in most other surrounding areas. B-gene frequencies are mostly between 10 and $15 \%$, as in eastern Europe. In conformity with previous findings in the same area we find the Turks of Mersin to have $28.5 \%$ of $\mathrm{A}$ genes and the Eti-Turks $30.5 \%$. The Turks of Mersin have a B frequency near the top of the normal Turkish range, while the Eti-Turks lie below it. Neither of these populations shows any influence of the neighbouring Yürük nomads (Irmak, 1938) with their very low A and B frequencies, near to those of the Yemenite Arabs and Jews. The frequencies found for the $A_{2}$ gene in both the populations which we have tested are surprisingly high, but there are no previous observations in Turkey for comparison and few, if any, on neighbouring populations.

The MNS chromosome frequencies have a typically European aspect. The total frequency of the $M$ gene in the Turks themselves is in fact rather low even for Europe. As Ikin (1958) has pointed out, the rather higher frequency of $\mathbf{M}$ in the Eti-Turks and their high frequency of MS may be related to the high $M$ and $M S$ frequencies found in Arabia.

The frequencies of the $\mathrm{Rh}$ groups also are essentially European-the rather high frequency of the chromosome $\mathrm{CDe}$ and the somewhat low frequency of $\mathrm{Rh}$ negatives and of the chromosome cde are typical rather of the Mediterranean area than of northern or central Europe. The relatively high frequency of $\mathrm{CDE}$ in both populations, especially the main Turks, seems to be an eastern European characteristic, though found also in Armenians and Iraqi-it is not found in the Mediterranean area as a rule. Perhaps, however, the most important feature of the $\mathrm{Rh}$ groups is the very low frequency of the chromosome $\mathrm{cDe}$ in both populations, showing a virtual absence of African ancestry, in marked contrast to nearly all other populations so far tested living around or near the eastern Mediterranean. Especially high frequencies have been found in other Moslem populations and attributed to the incorporation in them of negro slaves. The frequencies of the Lutheran $\left(\mathrm{Lu}^{\mathrm{a}}\right)$, Kell $(\mathbf{K})$, and Duffy $\left(\mathrm{Fy}^{\mathrm{a}}\right)$ genes are essentially European, but the frequency of Fya in the Turks shows a slight tendency towards the high frequencies found everywhere else in Asia.

\section{Abnormalities of Haemoglobin Synthesis}

Thalassaemia.-This is well known to occur in Turks (Frank, 1941 ; Tavat, 1941 ; Saraçoglu, 1943 (Macedonia); Fakaçelli, 1947 ; Aksoy, 1950 ; Aker, 1951 ; Frank et al., 1951 ; Römer and Dörken, 1956). Sickle-cell thalassaemia has been reported in Eti-Turks (Aksoy and Lehmann, 1957a ; Aksoy, 1958), and some of the subjects in whom the increase of the haemoglobin $A_{2}$ fraction associated with thalassaemia has been studied by Crowley et al. (1957) were Eti-Turks. Thalassaemia, which is very common in Cypriots generally, has been seen in Turkish-speaking Cypriots (Fawdry, 1944, 1946; Aksoy, 1952), and recently in four Turkish Cypriot families in London (Lehmann, unpublished observa- tions). In 60 haemoglobin samples from Eti-Turks which on electrophoresis showed haemoglobin $\mathbf{A}$ as the only adult haemoglobin type, the alkali-resistant fraction was measured by the method of Singer, Chernoff, and Singer (1951); four showed a percentage above 2 . It is likely that these blood specimens came from carriers of the thalassaemia gene. As the specimens came from out-patients, who may have included a higher proportion of persons with thalassaemia minor than a true random sample of Eti-Turks, it is likely that the incidence of thalassaemia amongst the Eti-Turks is less than $7 \%$. Of 240 specimens from Turks from the same region only one showed an increase of haemoglobin $\mathbf{A}_{2}$. However, recently five additional cases of thalassaemia major and several of thalassaemia minor have been observed in this group (Aksoy, 1958).

Sickling.-The first case of sickling in Turkey was reported in a young woman from the island of Marmara (Egeli and Ergun, 1946). The second instance came from Mersin (Küley and Tuna, 1953). Aksoy (1955, 1956) has drawn attention to the high frequency of sickling and of sickle-cell disease in the Eti-Turks living in the southern part of Turkey in and near Mersin, having found the incidence of sickling in 376 hospital out-patients and their healthy relations to be $13.3 \%$. In the present series of 138 Eti-Turks the observed incidence was $46.6 \%$. The specimens were, however, taken from hospital out-patients, many of whom were known to be suffering from sickle-cell disease, and from their relatives. There can therefore, of course, be little doubt that the observed incidence considerably exceeds that which would have been found in a random sample of Eti-Turks. No example of sickle-cell haemoglobin was found among the 240 samples from Turks.

Haemoglobins $E$ and D.-Haemoglobin $\mathrm{E}$ was found twice in 138 Eti-Turks. One of them was a haemoglobin $E$ trait carrier (Aksoy et al., 1955), and the other the first instance of sickle-cell haemoglobin E disease (Aksoy and Lehmann, 1957b). After the conclusion of the present survey

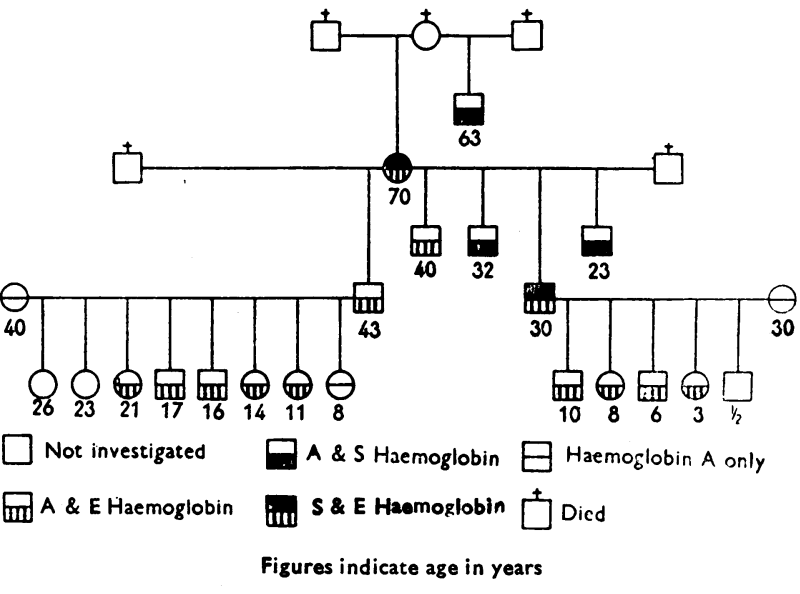

The Eti-Turk family with haemoglobins A, S, and E. This pedigree contains some corrections to that previously published in Nature (Lond.) (1957). The conclusions then advanced are not affected by these changes.

the family of the woman with sickle-cell haemoglobin $E$ disease was examined and 11 haemoglobin-E trait carriers and one other person with sickle-cell haemoglobin $\mathbf{E}$ disease were found (See Fig.). Haemoglobin D was found in one of the 240 Turks tested, and further instances were seen in her family, the members of which are not included in the series of 240 (Aksoy and Lehmann, 1956).

\section{Discussion}

Generally speaking, as regards their blood groups, both Turks and Eti-Turks share the characteristics of the peoples of southern and eastern Europe rather than of Asia, and African characteristics are conspicuously absent. The differences between the Turks and Eti-Turks are slight, but, such as they are, they show the Turks, with higher frequencies 
of B and Fya, to tend perhaps a little more towards Asiatic features than the Eti-Turks, who have, however, the higher frequency of $M$.

As regards abnormalities of haemoglobin synthesis, we have seen that thalassaemia, as its name implies a Mediterranean character, but not exclusively so, exists in both populations. Sickling, generally regarded as an African character, appears to be extremely rare in Turks and has not been found in the present survey, but is found at a high frequency, almost certainly above $10 \%$, in the Eti-Turks. Haemoglobin E, perhaps derived from south-east Asia, is found sporadically in Eti-Turks, and haemoglobin D has been found in one Turkish family.

The most difficult character to account for is the sickling, in the absence of other African features. The situation in this respect does not appear to differ greatly from that found in the Lake Copais area of Greece (Choremis et al., 1957), and, as in that area, it is possible that a single sickling individual from Africa or elsewhere, or a small number of them, may have introduced the gene for haemoglobin $S$ into a highly malarious area, where the advantage conferred on heterozygotes by this gene in resistance to infection caused carriers of it to multiply selectively.

\section{Summary}

The ABO, MNS, Rh, Lutheran, Kell, and Duffy blood-group frequencies of the Turks and Eti-Turks of the Mersin area do not differ greatly from the values commonly found in Europe. Thalassaemia is present in both populations and sickling in the Eti-Turks, in whom its propagation may have been favoured by the prevalence of malaria. Haemoglobin E occurs sporadically amongst the Eti-Turks, and haemoglobin $\mathrm{D}$ was found once amongst 240 Turks.

M. A. is grateful for support from the Blood Research Foundation, Washington, D.C. The blood-group investigations included in this paper form part of a research carried out by. E. W. I. as a candidate for the degree of D.Phil., London.

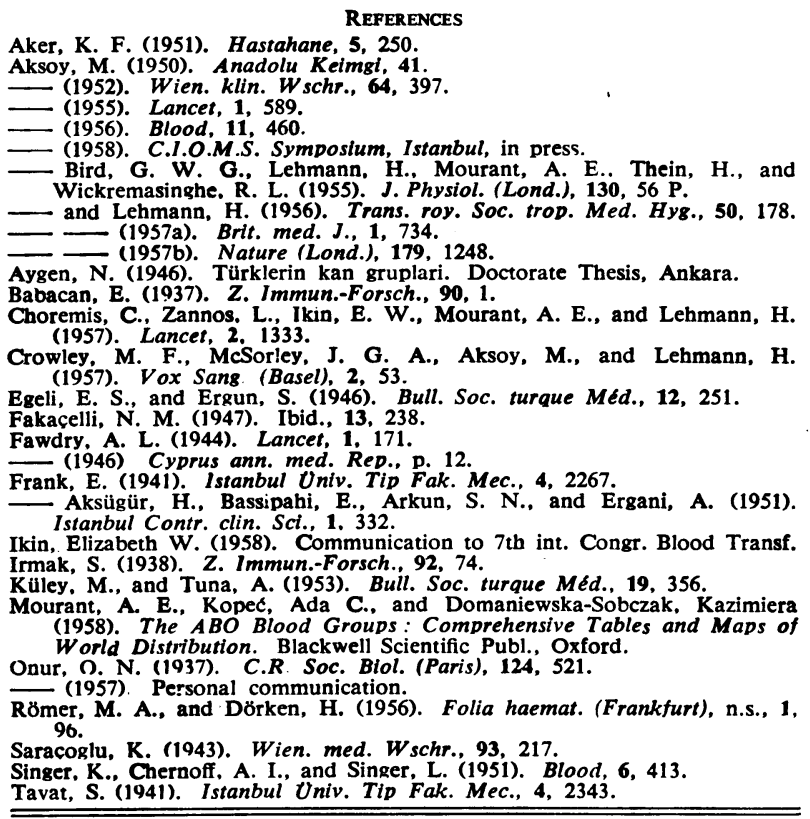

According to their Annual Report for the year 1957 the British Red Cross Society continued to play a big part in the Hungarian Relief programme during that year. In consultation with the International Committee of the Red Cross, equipment was supplied for two hospitals severely damaged during the rising. In Austria approximately 113,000 refugees were looked after by the Red Cross, the British Red Cross contributing food, clothing, and a certain amount of medical and nursing care in 44 camps.

\section{A BLOOD TRANSFUSION SERVICE IN CYPRUS}

WITH NOTES ON THE ABO GROUPS OF CYPRIOTS

BY

\author{
P. A. CLEARKIN, O.B.E., M.D., D.P.H. \\ Lately Government Pathologist, General Hospital, \\ Nicosia, Cyprus
}

Until 1953 endeavours to establish a blood bank in Cyprus, based on the voluntary system of recruitment of donors, resulted in failure, as volunteers did not come forward in sufficient numbers. The absence of a blood bank was severely felt, since transfusion could be given only when friends and relatives of a patient offered their blood. As no stocks of blood were kept this involved delays in obtaining donors, and grouping, cross-matching, and taking blood immediately before a transfusion could be given, thus causing delays which sometimes resulted in loss of life in an emergency.

In 1953 it was decided to try once again to establish a blood bank. Preliminary attempts to form a panel of donors failed again in spite of all the efforts of the local branch of the Red Cross, so another system of obtaining donors was tried, which proved successful. During almost five years it has functioned through difficult times and many emergencies, and never failed to provide adequate supplies of blood when called upon.

\section{Methods of Founding the Blood Bank}

The system employed consisted in laying the onus for providing donors on the medical practitioners who wished to use the services of the bank. Each medical officer in charge of a ward in the hospital was required to open an account by supplying two or more donors, and for each two donors he was credited with one bottle of blood. He was allowed to draw blood from the bank up to the extent of his credit, but overdrafts were permitted at the discretion of the director, or, alternatively, a ward which was overdrawn could borrow from another whose credit was good. In other words, the bank was organized on the same basic principles as an ordinary commercial bank except that interest was not charged on overdrafts.

Donors were drawn from friends and relatives of patients who required a transfusion or who were about to undergo a major operation. Accounts were rendered to each ward every Monday morning.

When the bank was opened there was some reluctance on the part of friends and relations of patients to donate blood. They could not see the necessity for doing so, as there was now a blood bank. Some little trouble had to be taken to impress on them that it was a Cypriot blood bank for Cypriots and that it would have to be supported by Cypriots. (There seemed to be an impression that the European community and young Service men would contribute all the blood necessary.)

Once the initial period of education of the public and the medical profession was over there was no difficulty in obtaining donors and maintaining an adequate stock of blood. Requests then came from private clinics for blood, especially in emergencies, and it was agreed to admit such clinics to participation in all the services of the blood bank on the same terms as the hospital. The service was next extended to the two largest towns, Limassol and Famagusta, and it was hoped to extend it to Paphos eventually. The two other large towns, Kyrenia and Larnaca, dealt direct with Nicosia, and blood was dispatched to them in refrigerated boxes.

All the services of the bank were free, and included provision of blood accompanied by a sterile transfusion set, blood 